\title{
An Exploratory Study of the Cultural Values of Cameroon's Young, Elite, Urban Population: Implications for Management and International Business
}

\author{
Casimir Barczyk \\ Purdue University Northwest \\ Charles Rarick \\ Purdue University Northwest \\ Gregory Winter \\ Alcorn State University
}

\begin{abstract}
The cultural orientation of Cameroon's young, urban elite population is assessed using Hofstede's Value Survey Module (VSM 2013). The survey questionnaire contains 30 items that tap into six cultural dimensions. Cameroon was not included in Hofstede's original or subsequent studies. While there has been research on the national culture of other African countries, there is a dearth of empirically based studies on Cameroon's cultural classification. The VSM 2013 was administered to 50 individuals enrolled at a major university. This represents a distinct segment of the country's population. Analysis of the data revealed that the Cameroonian people are low in power distance, strongly collectivistic, somewhat feminine in nature, and highly accepting of uncertainty. They possess a short-term orientation towards time and are restrained in the expression of impulses and desires. This paper compares the cultural dimension scores found in Cameroon to other countries in the region and beyond. The results show cultural similarities and differences with other global nations including Brazil, China, Germany, and the USA. Implications for management and international business are discussed.
\end{abstract}

Keywords: Cameroon, Hofstede, culture, urban elite

\section{INTRODUCTION}

Cultural values are a symbolic reflection of the differences between nations of the world. They exert a considerable influence on both personal and organizational life. Business organizations develop policies and practices that reflect cultural differences, which are recognized as one of the more influential factors affecting performance. Sagiv and Schwartz (2007) maintain that a company's values are more important than market forces in explaining success in international business. National culture is another critical factor that organizations need to consider when strategically managing performance. It is deeply rooted in values, which are inextricably connected to daily life.

As international business organizations set a trajectory for the future, it becomes clear that Africa is an important part of the world that is becoming ripe for development. The continent has exhibited a positive 
record of growth in recent years, and it is positioned for further expansion. This is especially true for Cameroon, a stable independent country situated in Central Africa.

\section{HIGHLIGHTS OF CAMEROON}

Cameroon was founded as a German colonial settlement in 1888. It established independence from a UN trusteeship in 1960. A year later it merged with the southern portion of neighboring British Cameroon as a federal republic. In 1972 a new constitution was adopted that effectively replaced the federation with a unitary state known as the Republic of Cameroon (CIA World Factbook, 2020).

Cameroon is geographically situated between Equatorial Guinea and Nigeria, bordering the Bight of Biafra. It measures 475,440 square kilometers, an area slightly larger than California. Cameroon's population in 2020 is estimated at 27,745,000. The official languages of the country are French and English (CIA World Factbook, 2020).

Cameroon is often called "Africa in miniature" because of its diverse landscapes representing the continent's numerous climatic zones. Cameroon has major economic strength in its relatively well trained and qualified labor force. The country boasts having one of sub-Saharan Africa's more developed educational systems (Staff Writer, Maritz Africa, 2015). Growth in Cameroon is predicted because of moderate population increases, rapid urbanization, and rising incomes. More than $60 \%$ of the populace is under 25, suggesting a rather large youth population. Non-rural regions of the country are experiencing economic growth (CIA World Factbook, 2020). Cameroon is seeking to improve its somewhat undesirable climate for business enterprise by embarking on various World Bank and IMF programs to spur international investment and improve trade. An important part of the country's business climate can be linked to cultural factors. In this paper we suggest that Cameroon's profitable engagement in international business requires partners to understand the country's national culture. This implies an understanding of the people's values and beliefs.

The world today has become a global village where technology brings people of various nationalities and cultures together. This environment creates challenges for business. One is the uncertainty on how managers, workers, suppliers, and customers need to relate to one another. This may be frustrating because it is sometimes unclear what one should say when encountering someone from another culture. One needs to assess whether there are cultural taboos that determine what one should or should not do when interacting, or whether even a smile is appropriate. A failure to understand and appreciate these cultural expectations along with the system of beliefs held by people in a particular country can lead to organizational disharmony. This could potentially have negative effects on productivity, customer satisfaction, and international business relations. The findings summarized in this paper, using a well-established pragmatic framework, will assist business leaders and decision makers in organizations to develop an understanding of Cameroon's cultural values. They provide insights on how everyone involved in international business partnerships can harmoniously co-exist through an appreciation of Cameroon's national culture as reflected by its emerging younger, educated and elite population.

\section{HOFSTEDE'S CULTURAL VALUES}

One of the most popular and far-reaching frameworks for the understanding of national cultural differences is that of Geert Hofstede. His framework explains the distinct dimensions that account for differences between cultures of individuals from different countries. As an industrial psychologist who headed the personnel research unit at IBM-Europe, Hofstede developed a "values" survey and administered it to employees in 72 national subsidiaries of IBM during the 1960s and early 1970s. His ground-breaking findings changed our view of managers and the work of managing across national cultures.

From his analysis of employees at IBM, Hofstede identified six cultural dimensions that impact workrelated values in different countries. The dimensions relate to six anthropological problem areas that societies address in different ways. They determine the behavior of workers from different cultural backgrounds in an organization. Hofstede proposed that theories of organizations and management were 
not universal. Rather, they were bound by culture. As such, managerial behavior considered appropriate in one culture may be inappropriate in other cultures (Hofstede, 1980a; Hofstede, 1980b; Hofstede, 1983; Hofstede, 1993; Hofstede, 1994; Hofstede, 2001). Hofstede's findings have been widely cited in academic and professional literature across numerous disciplines (Kirkman, Lowe \& Gibson, 2006). His work often serves as a foundation for cross-cultural analysis in university business courses. From his initial survey of 72 countries, Hofstede was able to profile 40 different cultures. Subsequent research provided for the classification of 10 additional countries as well as three global regions (www.geert-hofstede.com, 2014).

Hofstede and Minkov (2010) believe that the cultural dimensions represent ways that societies from different countries cope with inequality, relationships between individuals and groups, the emotional implications of being born a boy or girl, uncertainty, the future, and the extent to which human desires are expressed or suppressed. Each of these six problem areas will be described in terms of Hofstede's cultural dimensions.

Power distance (PDI) refers to the degree of existing and acceptable inequality among people with and without power, i.e., the leaders and the led. A high employee power distance indicates that an unequal distribution of power in that society is acceptable. Workers without power understand their situation clearly and recognize their place in the system (Hofstede, 2003). A low employee power distance implies equitable sharing and distribution of power. In such a society members view themselves as equals. Countries with low power distances typically have workers and supervisors that regard each other as equal, separated only by chance, opportunity, and perhaps luck. Countries with high power distances typically have organizations that have big gaps in compensation, respect, and authority between workers and managers.

Individualism (IDV) refers to the strength of the connections people have to others in their communities. According to Hofstede (2003), a high individualism score suggest a loose connection with people or little sharing of responsibility among members of that society. Socialization occurs only with a few close friends and members of one's family. There tends to be a high value for freedom. In other words, people in such a society prefer to be left alone. They enjoy challenges and expect rewards for the work they individually perform. This is contrasted with societies low on individualism, which are considered collectivistic. Those societies emphasize harmony. People there prefer to work with others for the collective or societal good, rather than for the individual good. With collective cultures, workers prefer close supervision and interaction with managers. There tends to be a preference for less individual tasks and more team assignments. This work arrangement is one where team effort is recognized and rewarded.

Masculinity (MAS) refers to the extent to which a society maintains traditional roles for females and males. In highly masculine cultures men are supposed to be assertive and tough. They value material goods and see themselves as providers for their families. They are unquestionable authority figures over women. By contrast, highly feminine cultures value relationships, nurturing, and a concern for others.

Uncertainty avoidance (UAI) is the extent to which societal members feel insecure when encountering unknown or uncertain situations. Cultures with high uncertainty avoidance have a fear of the unknown resulting in the avoidance of ambiguity. It is guided by rules and order in the pursuit of a collective "truth." Conversely, cultures with low uncertainty avoidance enjoy situations that are unknown and its people value diversity. There are typically less rules and an acceptance of ambiguity. People desire to discover their own truth.

Long term orientation (LTO) is an addition to Hofstede's original set of four cultural dimensions. Hofstede and Bond (1988) formulated a fifth dimension, earlier called Confucian dynamism. It refers to the extent that society values, encourages, and rewards behavior that is future oriented such as delayed gratification, planning, and investing in the future. In high long-term oriented cultures, families are seen as the bases for society. Parents and men have more authority than women and young people. Those cultures have people with a strong work ethic and a value for education and training. By contrast, cultures with a low long-term orientation promote equality and seek self-actualization (Makambe \& Pellissier, 2014).

The last cultural dimension, known as indulgence/restraint (IVR), was uncovered in further research (Minkov \& Hofstede, 2011; Minkov, 2013). It refers to the extent that a society permits or suppresses the expression of human desires. It can be viewed as a barometer of people's attempt to keep their impulses and desires under control, based on socialization, i.e., the way they were raised. In indulgent cultures people 
have very weak control. In restrained cultures, by contrast, people have relatively strong control over their desires.

\section{CRITICS OF HOFSTEDE'S APPROACH}

Over time, Hofstede's cross-cultural research has gained great popularity. As such, it has resulted in the development of competing models such as Schwartz's theory of basic cultural values and the GLOBE Project (Moalla, 2016). It has also resulted in viewpoints critical of Hofstede's cross-cultural research. Critics question the generalizability of his findings, the level of analysis, the assumption of a country's geographic boundaries as cultural entities, and the statistical rigor of his survey questionnaire (Blodgett, Bakir, \& Rose, 2008; McSweeney, 2002; Smith, 2002). Some critics have questioned the assumption of the homogeneity of the cultures analyzed (Sivakumar \& Nakata, 2001). Others have challenged not only Hofstede's findings, but also the GLOBE study findings, and have cautioned against using their conclusions to further marketing research and practice (Venaik \& Brewer, 2013).

The conceptual validity of Hofstede's dimension on long term orientation has also been criticized (Fang, 2003). The ecological fallacy is a problem in Hofstede's work. Grenness (2012) states that this occurs when the predominant traits of a culture are generalized to individuals within that cultural group without taking account individual differences. Some critics believe that cultures change over time (Beugelsdijk, Maseland \& Van Hoorn, 2015) and as such, the original Hofstede rankings may be dated and inaccurate. Still others have questioned whether national culture is a valid construct and whether it has value in predicting organizational behavior (McSweeney, Brown \& Lliopoulou, 2016).

In sum, there appears to be some validity to the many concerns raised by Hofstede's critics. However, his model, approach, and research work represent the oldest and most comprehensive analysis of cultural values. All subsequent models of national culture include Hofstede's dimensions or have conformed to his approach (Oppong, 2013). Even Trompenaars (1993), who offers a competing model of culture, acknowledges Hofstede for opening the eyes of managers to the importance of cross-cultural dimensions to business and management. Notwithstanding their criticisms, Blodgett, Bakir, and Rose (2008) commend Hofstede for conducting what they call pioneering work that brings the concept of culture to front view in the behavioral sciences. It would be difficult to find a theory of cultural classification without limitations and its own set of critics. Jackson (2011) calls Hofstede's approach "blunt", but it nevertheless provides valuable insights for understanding important cultural values.

The authors of this paper provide a broad overview of the cultural values of Cameroon, a country not included in Hofstede's data set. Cameroon is a complex, diverse country consisting of a large youthful population under 25 . The country is facing rapid urbanization and economic growth in non-rural regions. It has a well-trained labor force (CIA World Factbook, 2020). An accurate research-based assessment of Cameroonian culture is nearly impossible because of the differences in language and economic status among its people. However, one can glean some light into a subset of the country's culture that is perhaps most relevant for engaging in international business and closely resembles the cultural findings of the Hofstede studies. Arino (2015) stresses the importance of understanding the culture of Cameroon, especially if companies are engaged in or plan to do business in the country or on the African continent. Companies in Africa need to draw on indigenous cultural practices to improve their management operations and facilitate the transformations necessary to make their organizations more competitive (Swartz and Davies, 1997). Having an awareness of cultural differences prepares managers and business owners for what to expect from individuals that come from other cultures and informs them on appropriate ways to interact (Makambe and Pellissier, 2014).

In sum, companies in Cameroon and especially those involved in international business, must understand the behavior of Africans at work. It is critical because Cameroonian workers will always be influenced by their cultural values - and recognition of those values could serve to promote effective management. 


\section{Method}

\section{Respondents}

This study assesses the cultural dimensions of Cameroon using a random sample of 50 students attending a major university. There were an equal number of male and female respondents. The sample was primarily, but not totally, comprised of urban dwellers. The average age range of the respondents was 2024. The sample represented the more elite segment of Cameroonian society.

\section{Survey Instrument}

This study uses the Hofstede Value Survey Module 2013 (VSM 2013). It is the version of Hofstede's questionnaire that has all six dimensions of culture (Hofstede, 2013). It contains items developed for comparing the culturally determined values of people. When administered to the respondents, the 30 -item questionnaire measures respondents' perceptions of Cameroonian culture on the value dimensions of power distance (PDI), individualism (IDV), masculinity (MAS), uncertainty avoidance (UAI), long-term orientation (LTO), and indulgence/restraint (IVR).

\section{Procedure and Analysis}

The VSM 2013 questionnaire was administered during class periods at the university by the course instructor. Students in the course were asked to voluntarily participate in the research study. After providing consent, they completed the survey questionnaire anonymously. Students then returned their questionnaires to the instructor.

The data contained in the survey questionnaires were analyzed using Hofstede's index method. Using the prescribed method, scores were computed for each of the six cultural dimensions. A constant adjustment from the index formula was employed using Hofstede's previous research that grouped West African countries.

The value dimension scores obtained for Cameroon were compared to those obtained by Hofstede for other countries of the world (www.geert-hofstede.com, 2012). The scores on the six dimensions were compared to four select countries and two regions of Africa. The countries and regions included were China, Brazil, Germany, USA, West Africa, and East Africa. Scores on the six dimensions in the current study were also compared to those from respondents who live in countries within the region for a deeper comparison. The countries included in this analysis were Ghana, Angola, Burkina-Faso, Nigeria, and Sierra Leone.

\section{RESULTS}

The findings of the survey analysis generally indicate that Cameroonian culture is moderately low in power distance, strongly collectivistic, somewhat feminine in nature, and very low in uncertainty avoidance. The culture is also short term in its orientation toward time and restrained in its expression of impulses and desires. These results suggest that there are some differences in the value dimensions scores for Cameroon as contrasted with other countries in the West African region. For example, power distance as well as uncertainty avoidance is lower in Cameroon as compared to countries in West Africa. Cameroon is lower in indulgence compared to other West African countries with the exception of Burkina-Faso whose culture is even more restrained. While its score of 12 indicates that Cameroon is short term oriented, its score is lower than in other West African countries except for Ghana whose culture is even more short term oriented. Cameroon's strongly collectivistic and relatively feminine culture is similar to other countries in West Africa. Figure 1 shows the scores for Cameroon and Germany, its colonial overseer, on the six cultural dimensions using Hofstede's (2013) 6-D model.

Cameroon was a German colony for 72 years before it became an independent country in the 1960's. Based on the data in Figure 1 it appears that some aspects of German culture became immersed into Cameroonian culture. There are significant cultural differences between the two countries on four cultural dimensions. However, the two countries have similar values with respect to indulgence and power distance. 
This may be the result of Cameroon's colonial history. It seems more evident that Cameroon's culture, when viewed in totality, is unique and not a mirror image of German culture.

\section{FIGURE 1 \\ PLOT OF THE SIX CULTURAL DIMENSIONS IN CAMEROON AND GERMANY}

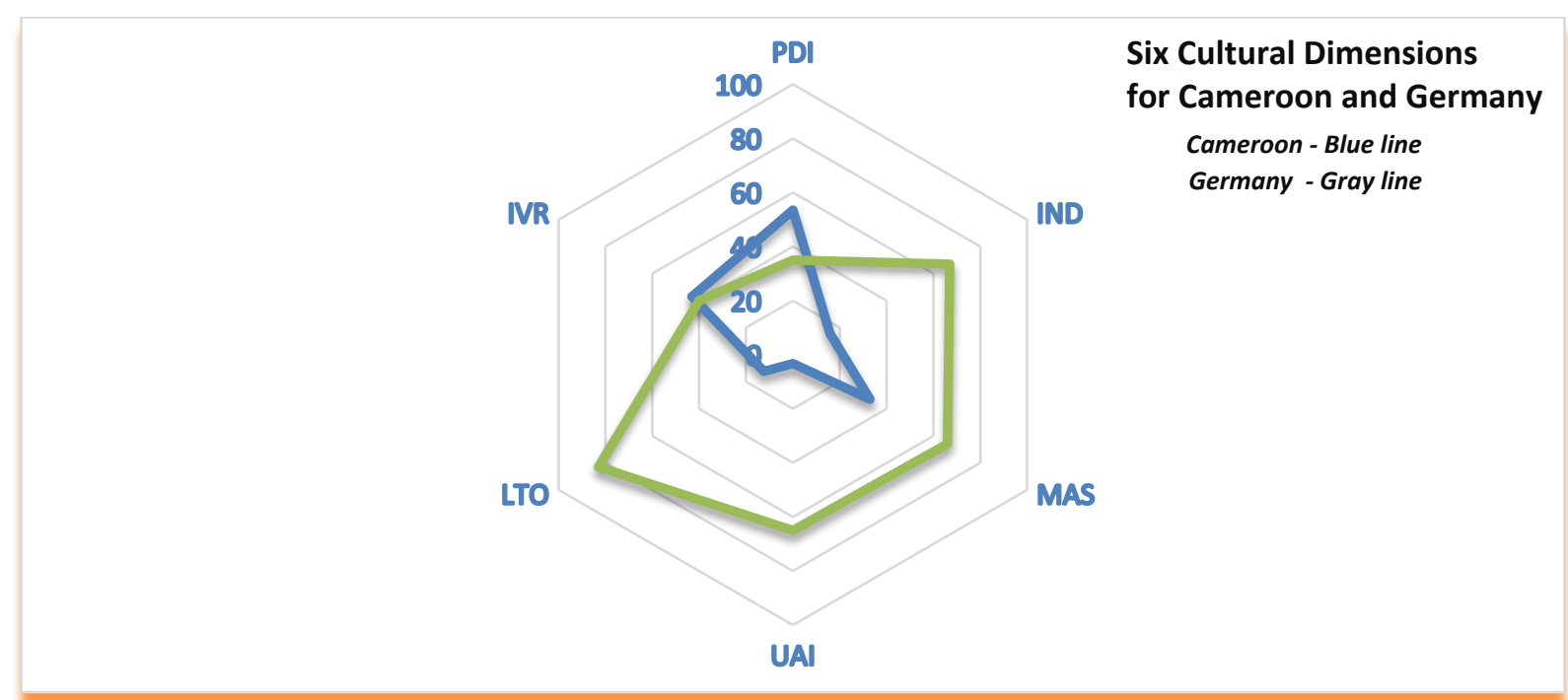

\section{Power Distance}

The data indicate that Cameroon has a PDI score of 54. This finding suggests that the people of Cameroon have a relatively low level of acceptance of inequality within its societal structure Figure 2 plots the data on this cultural dimension for Cameroon and select countries from around the globe. The data indicate that with respect to power distance, Cameroon's culture is moderately egalitarian, which is similar to the USA and Germany. However, the PDI scores in those two countries are even lower than in Cameroon.

\section{FIGURE 2 \\ SCORES FOR POWER DISTANCE IN CAMEROON AND SELECT COUNTRIES}

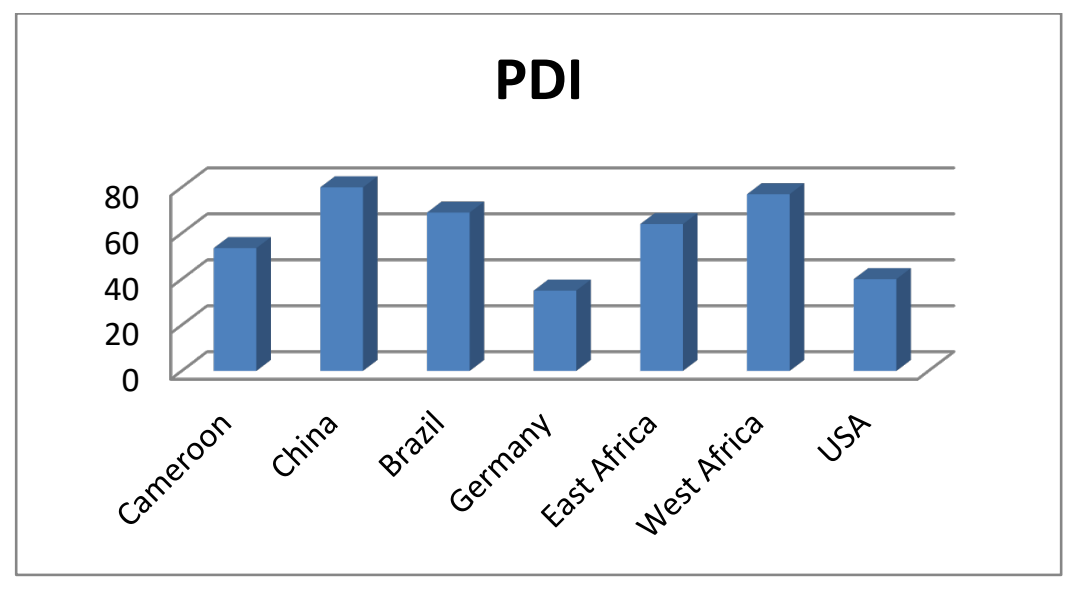

Figure 3 shows that with respect to other West African countries, Cameroon is lower in power distance than its neighboring countries. Cameroonian society appears to be structured with greater equality than in other countries within the region. 
FIGURE 3

SCORES FOR POWER DISTANCE IN CAMEROON AND SELECT AFRICAN COUNTRIES

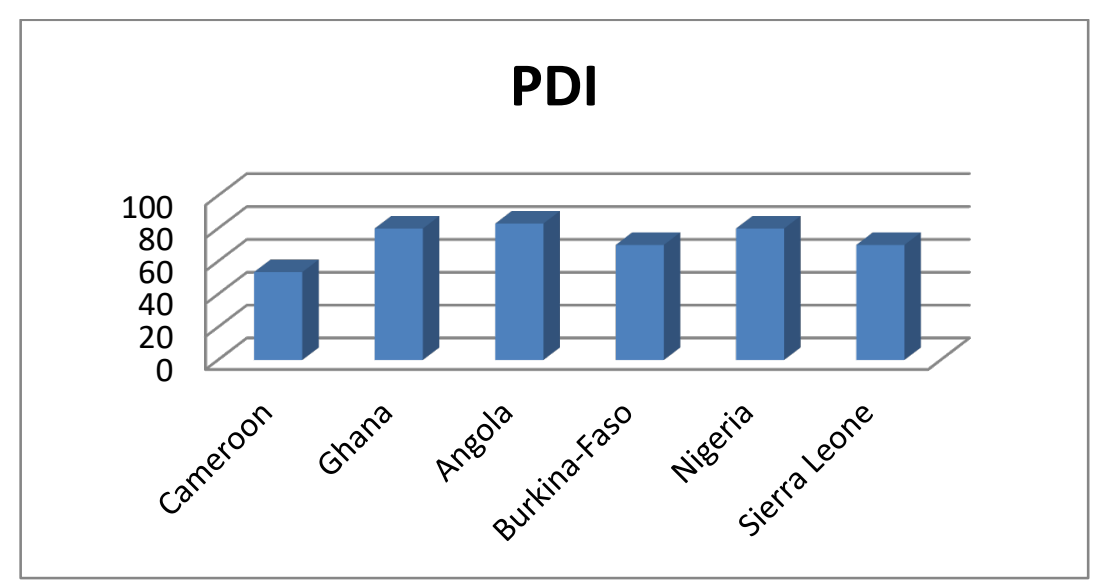

\section{Individualism}

The data indicate that Cameroon's IDV score is 16 , which suggests that its people are strongly collectivistic. Of the selected countries for comparison in this study, Cameroon is the most collectivistic, similar to countries in east and west Africa. Germany and the USA have the most individualistic cultures.

FIGURE 4

\section{SCORES FOR INDIVIDUALISM IN CAMEROON AND SELECT COUNTRIES}

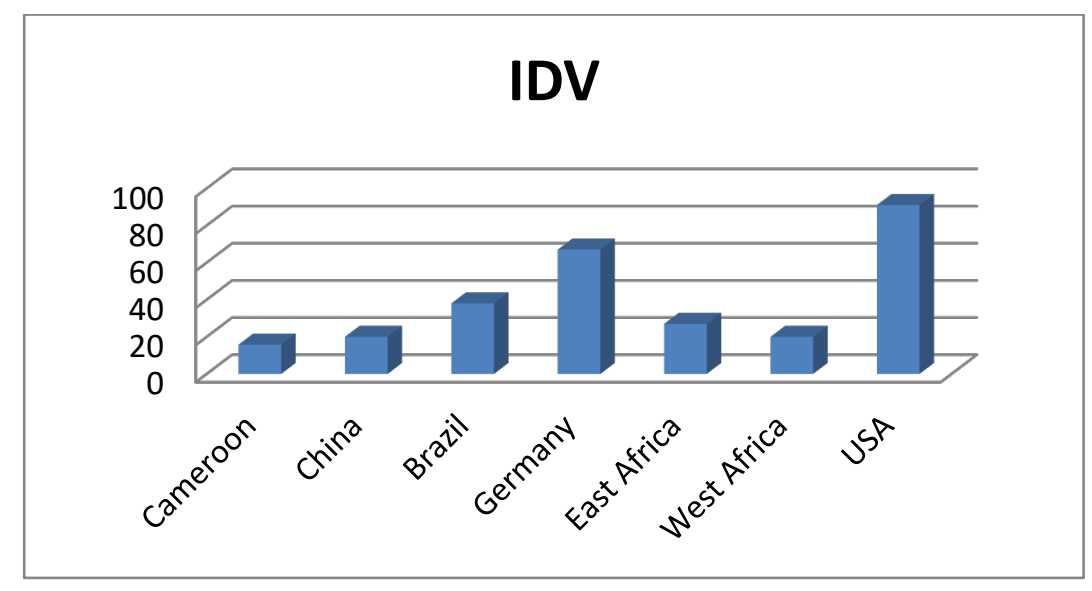

Figure 5 shows that within the region, Cameroon's IDV score is similar to those of most neighboring countries, except for Nigeria and Sierra Leone, both of which have cultures that are more individualistic. Clearly, Cameroon is a nation having a collectivistic culture. 
FIGURE 5

SCORES FOR INDIVIDUALISM IN CAMEROON AND SELECT AFRICAN COUNTRIES

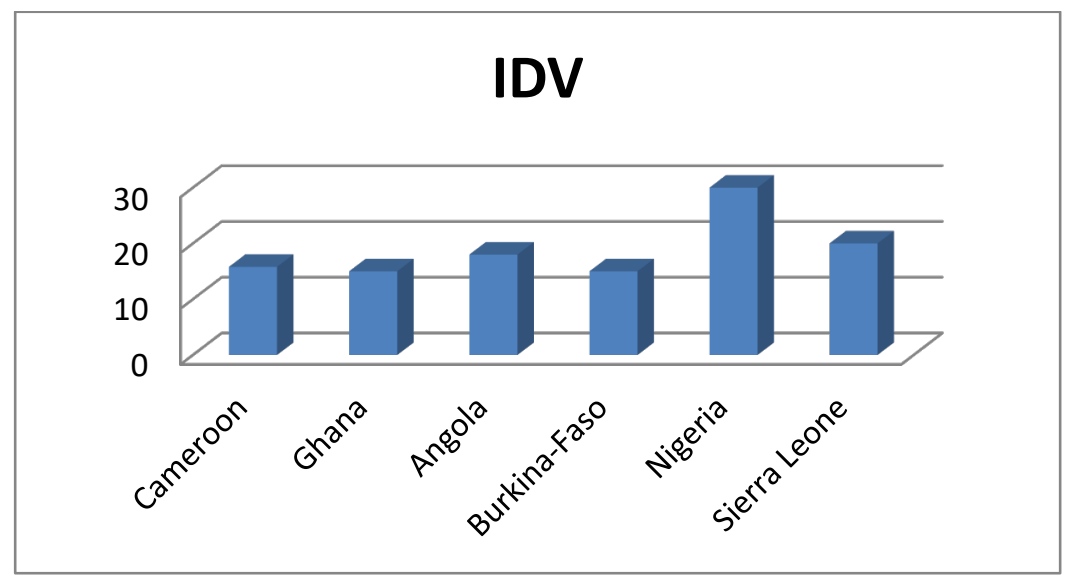

\section{Masculinity}

The data indicate that Cameroon has an MAS score of 33. As such, Cameroon's culture is more feminine oriented than masculine. Figure 6 shows the MAS scores for Cameroon and select countries. It is similar to the countries in the East African region and distinctly less masculine than China, Brazil, Germany, West Africa and the USA.

FIGURE 6

SCORES FOR MASCULINITY IN CAMEROON AND SELECT COUNTRIES

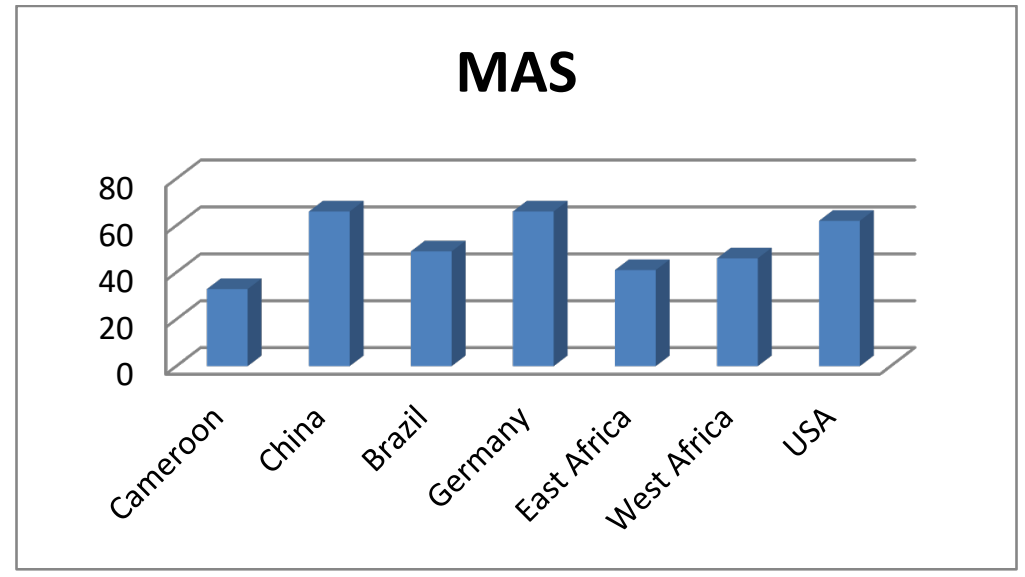

Figure 7 shows that Cameroon's MAS score is slightly lower than most countries in the region. The only exception to this generalization is Angola, whose culture is the least masculine of all countries in this analysis. Clearly, both Cameroon and Angola are feminine-oriented nations. 
FIGURE 7

SCORES FOR MASCULINITY IN CAMEROON AND SELECT AFRICAN COUNTRIES

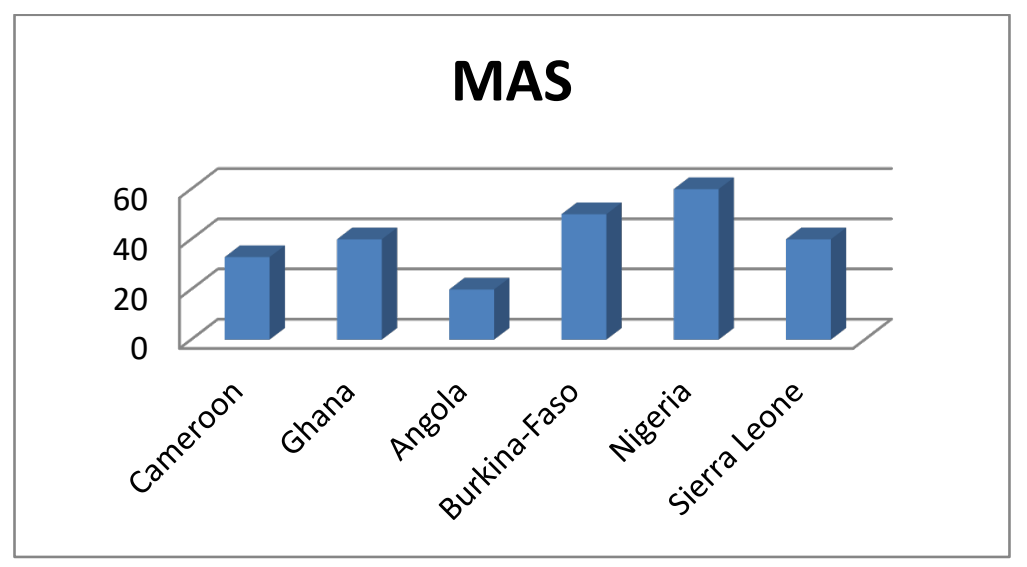

Uncertainty Avoidance

The data indicate that as a society, Cameroon is very low in uncertainty avoidance with a UAI score of 3.3. As shown in Figure 8, Cameroon has the lowest UAI score among the select countries analyzed. It contrasts most with Brazil and Germany. The degree to which the people of Cameroon avoid uncertainty is even lower than that seen in the East and West African region. A country that is very low in uncertainty avoidance is accepting of change and comfortable with conditions that are uncertain. Rigidly constructed rules and procedures in organizations are seen as undesirable and unnecessary.

FIGURE 8

\section{SCORES FOR UNCERTAINTY AVOIDANCE IN CAMEROON AND SELECT COUNTRIES}

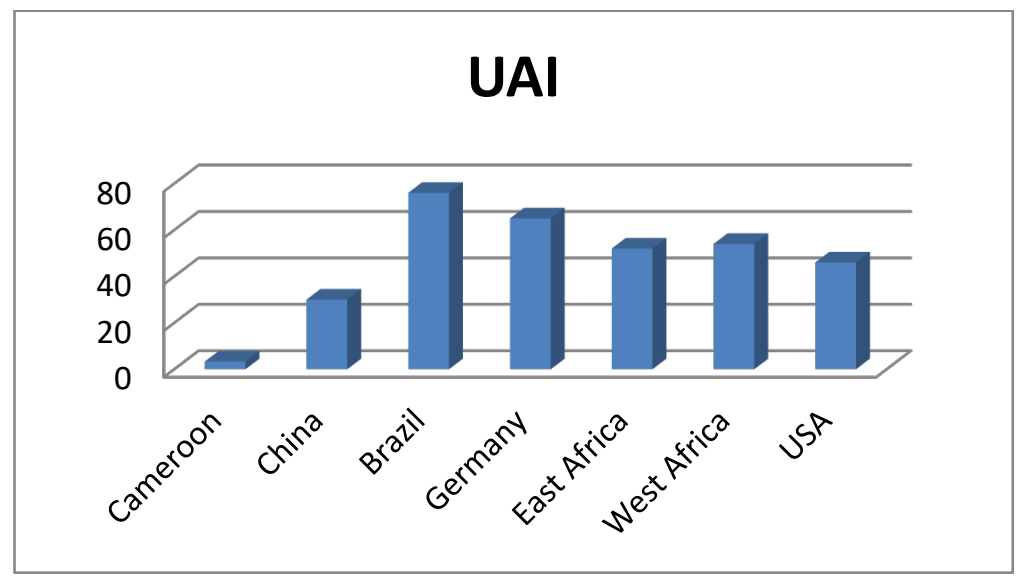

Figure 9 shows that Cameroon's UAI score is the lowest among the countries in the region. Neighboring countries have UAI scores that are considerably higher. All countries shown in Figure 9, except for Cameroon, show relatively high uncertainty avoidance. With a score of 50, Sierra Leone is the lowest scoring country in the region; but Cameroon even dwarfs it with its score of 3.3. Its culture has a greater tolerance for uncertainty than that typically found in neighboring countries. 


\section{FIGURE 9 \\ SCORES FOR UNCERTAINTY AVOIDANCE IN CAMEROON AND SELECT AFRICAN COUNTRIES}

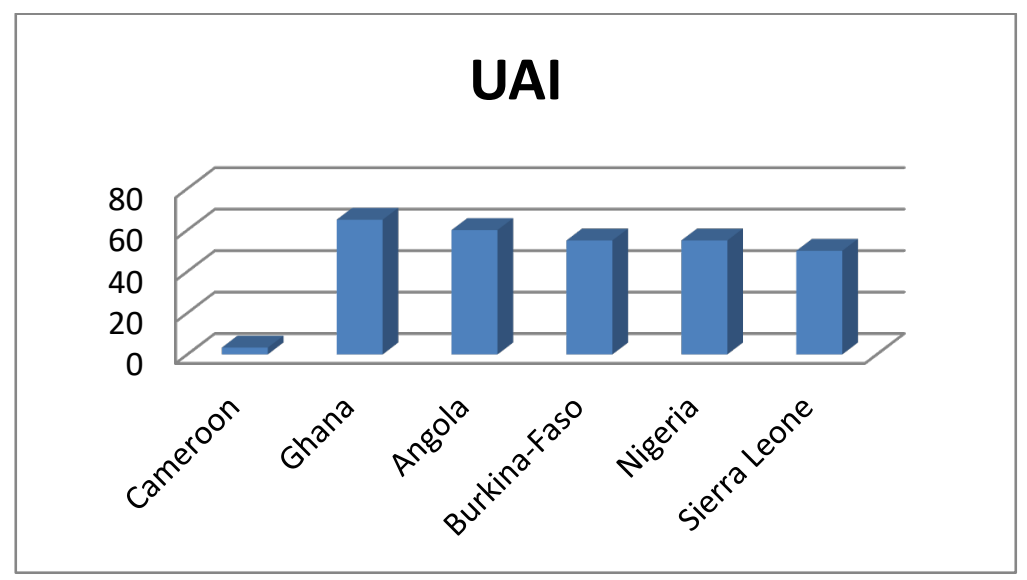

\section{Long Term Orientation}

The data indicate that Cameroon has an LTO score of 12.3, which indicates that it is low on long term orientation. Simply, Cameroon has a culture that is short-term oriented. Since this dimension was not included in Hofstede's original work, there is comparative LTO data for relatively few countries. Consequently, comparisons with the data from Cameroon are difficult. Figure 10 shows the LTO scores for Cameroon and select countries. It is aligned with other East African and West African countries, all of whom are short term oriented. Outside of the African continent, Cameroon is most similar to the USA, a country which is also short term oriented. Brazil, China, and Germany are all long-term oriented countries whose LTO scores are significantly higher compared to Cameroon. Hofstede and Bond (1988) suggest that cultures with low LTOs as is found in Cameroon respect tradition but desire quick results. There is likely to be social pressure to keep and advance one's social standing.

FIGURE 10

\section{SCORES FOR LONG TERM ORIENTATION IN CAMEROON AND SELECT COUNTRIES}

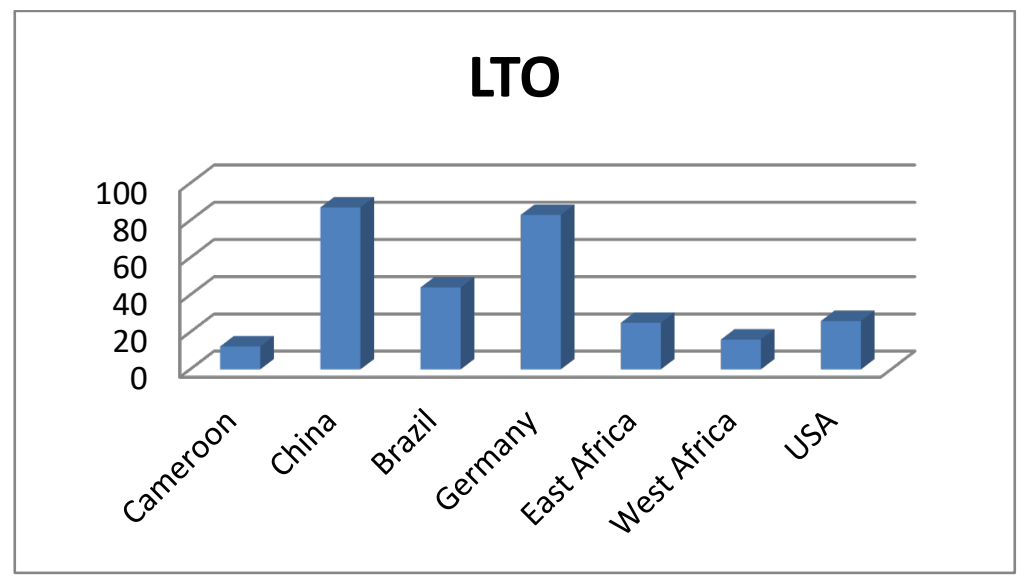

Figure 11 shows that Cameroon's LTO score is similar to that of neighboring Angola and Nigeria. Its score for long term orientation is higher than in Ghana and lower than is found in Burkina-Faso. There is no data available for Sierra Leone. Cultures with a low LTO score are present-oriented with a focus on 
quick results. With short term thinking, business decision-makers target their energies on what can be achieved with immediacy rather than in the long-run.

FIGURE 11

SCORES FOR LONG TERM ORIENTATION IN CAMEROON AND SELECT AFRICAN COUNTRIES

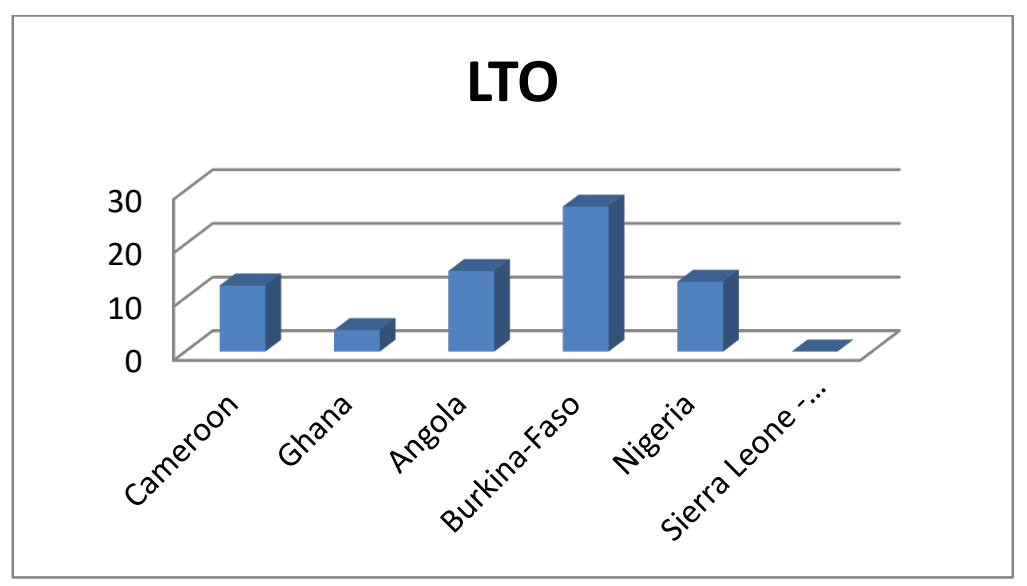

Indulgence vs. Restraint

The data indicate that Cameroon has an IVR score of 43, which suggests that it is a culture that values moderate restraint. Cultures that have a low IVR score tend to be pessimistic and cynical. Their people tend to control their gratification of desires. They perceive that social norms restrain them and believe that "indulging themselves is somewhat wrong" (www.hofstede-insights.com/country-comparison). Of the countries selected for comparison, Cameroon is similar to Germany and Brazil. It is most dissimilar to China, which has a much more restrained culture. By contrast, the USA is considerably more indulgent than Cameroon.

FIGURE 12

SCORES FOR INDULGENCE IN CAMEROON AND SELECT COUNTRIES

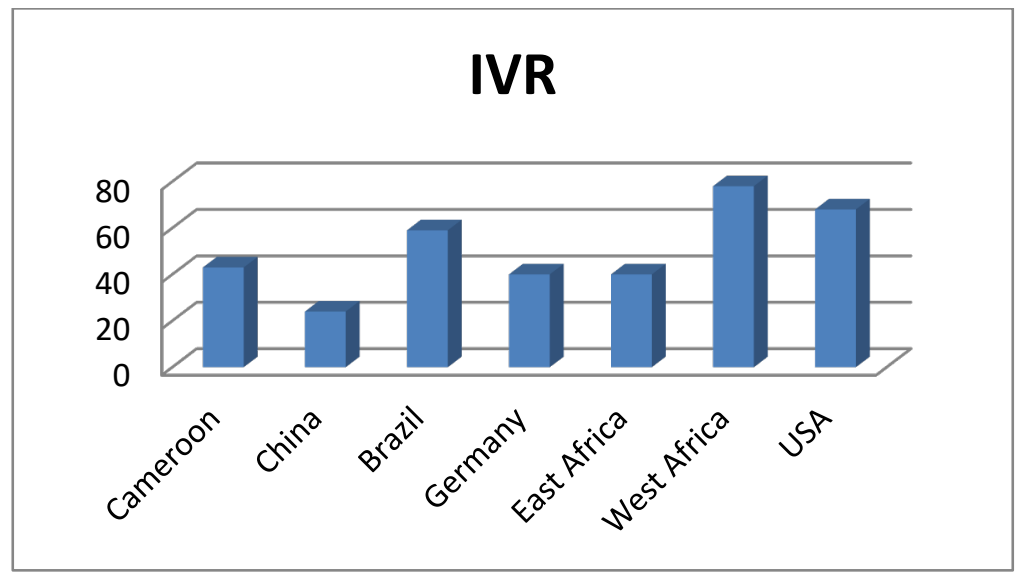


FIGURE 13

SCORES FOR INDULGENCE IN CAMEROON AND SELECT AFRICAN COUNTRIES

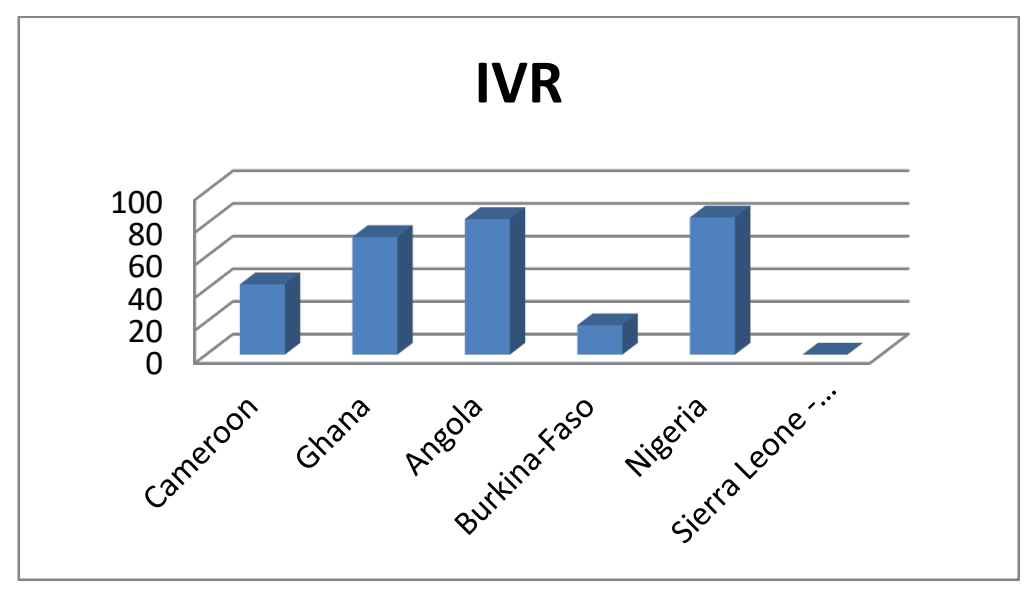

Figure 13 shows that within the region, Cameroon's culture is more restrained than that of Ghana, Angola, and Nigeria. They can best be characterized as indulgent. Burkina-Faso, however, is the most restrained culture of any neighboring country analyzed in this study. There is no data available for Sierra Leone.

\section{DISCUSSION}

National culture can be a major determinant of success for organizations involved in international business (Dartey-Baah, 2013). It is critical to understand the values, beliefs, and assumptions of people connected to organizations so that effective and harmonious relationships can be fostered. Cultural value systems drive attitudes, thinking, behavior, and actions. Value systems, according to Scarborough (1998) are closely linked to national as well as organizational culture. This ultimately impacts workplace behavior and managerial practices, factors that might affect subsidiary operations, joint ventures, and other forms of international business activity in Cameroon.

This study aimed to determine the cultural values of present-day Cameroon. It is thought that the results presented here are an accurate assessment of the wealthier, educated, urban segment of the Cameroonian population. The authors acknowledge that additional surveys using the VSM 2013, and more heterogeneous segments of the population would provide a clearer picture of the culture in Cameroon.

Surprising findings of this study of Cameroon's educated elite are the low score for power distance and the extremely low score for uncertainty avoidance. These cultural values could be useful in moving Cameroon forward in international business and economic development. To advance entrepreneurship and global thinking, it is helpful to build upon a cultural orientation that values the sharing of power and the acceptance of change. People from cultures low in power distance prefer some sort of participation and power sharing in the workplace. While Cameroon's relatively low PDI score may be a reflection of their people, it may also be a hold-over from its colonial connection to Germany, which has an even lower score and whose people are strongly participative in their work environment. Cameroon's propensity for power sharing and participation is consistent with an African cultural characteristic called "ubuntu," which is common with leadership behavior (Wanasika, Howell, Litrell, and Dorfman, 2011). Ubuntu is best described as leadership that is paternalistic, group oriented, and humanely focused. International managers planning to do business in Cameroon should be sensitive to these values. They should develop management styles that foster paternalism, share power with workers, and focus on the group.

Cameroon's very low score on uncertainty avoidance is another cultural factor beneficial to a country seeking to build its economic and political infrastructure. High uncertainty tolerance (i.e., a low UAI score) is associated with a country's ability to adapt to change. It is unlikely that massive change will occur in a 
short time in Cameroon, but there is some reason for hope that educated leadership in companies and politics will position the country for growth in international business.

Overall, Cameroonian society can be described as being restrained. Its people believe that the gratification of human desires related to enjoying life and having fun need to be curbed and regulated by norms. Indulgent cultures tend to focus more on individual happiness, leisure time, and freedom. Restrained cultures, like Cameroon, tend to downplay the importance of leisure time and freedom. Happiness and positive emotions are less freely expressed (MacLachlan, 2013). International managers must understand restraint as a cultural orientation in Cameroon because it runs counter to the values important for business and entrepreneurship. When people generally suppress gratification of wants and desires, purchase behavior tends to be diminished. With less buying, economic activity typically decreases. To compensate for this and thus stimulate consumption, businesses need to focus on materially rewarding accomplishment. People expect rewards for jobs well done. Objects such as cell phones, laptops, watches, and cars must be positioned as status items, rather than as purposeful necessities. Clearly, business strategies need to be finetuned to successfully navigate in Cameroon's restrained cultural milieu.

As globalization expands, frontier markets will remain an interest to companies involved in international business. Frequently, not much is known about the cultures of these isolated and more remote locations. Success in these and other markets requires a better understanding of the country's cultural values. In a McKinsey and Company report by Leke and Lund (2010), Africa was identified as a continent with countries being particularly important to international business. This was corroborated in a Harvard Business Review article by Chironga, Leke, Lund, and van Wamelen (2012). It was argued that the African continent is a desirable place to acquire natural resources. With globalization and planned structural changes, Cameroon, and by extension, the entire continent, are becoming increasingly important markets for exports and potentially strategic areas for manufacturing operations.

Bradley, Brown, and Rubach (2010) maintain that cultural understanding involves examining a country's past and its ingrained values of the present. To understand Cameroon requires an appreciation of its past, its colonization by Germany, and the emerging values of the current educated, elite, urban populace. Understanding Cameroon within Africa's diverse cultural mix and managing in a way that capitalizes on this knowledge are critical factors for success in international business. This paper sheds light on the cultural values of Cameroon as a promising frontier market.

\section{LIMITATIONS AND FUTURE DIRECTIONS}

Typical of many cross-cultural comparative studies, there is significant underreporting of less educated and more isolated members of the population. While the current work has similar limitations, the results provide a first attempt to gain a general assessment of the cultural values found in Cameroon. The unique characteristics of this study's sample population are not representative of Cameroon's total population and wider view of its culture. It is thought that the results reported accurately represent the cultural dimensions of the young, urban, educated segment of Cameroonian society.

In working to assess national culture, Hofstede (2013) recommends using matched samples for comparisons of countries. This study does not use that particular methodology. Clearly, having a matched sample to the original data would be ideal for comparison. However, without some generalizability of the original data set, the Hofstede studies would have very limited application. The VSM used by Hofstede and other researchers can best be described as a "blunt instrument" used to assess national culture. Even with this limitation, useful insights and knowledge about a country's culture can be obtained that would otherwise remain unknown.

While the sample size of the current study is limited, the usefulness of the findings for management and international business should not be wholly discounted. It should be remembered that sample size is not the only factor in determining a culture study's relevance and usefulness. Hofstede's sample from Pakistan, after all, had only 37 respondents. In this study the sample was balanced on the basis of gender. But it was made up of individuals whose educational attainment was above the national average. As such, 
future studies should be designed with a larger sample size and greater heterogeneity of participants. This would serve to increase the external validity and generalizability of the cultural research findings.

\section{REFERENCES}

Arino, A.M. (2015). Even neighboring countries are different. Africa From Africa Blog Network. Retrieved October 28, 2020, from https://blog.iese.edu/africa/2015/04/15/even-neighboringcountries-are-distant/

Beugelsdijk, S., Maseland, R., \& Van Hoorn, A. (2015). Are scores on Hofstede's dimensions of national culture stable over time? A cohort analysis. Global Strategy Journal, 5, 223-240.

Blodgett, J., Bakir, A., \& Rose, G. (2008). A test of the validity of Hofstede's cultural framework. Advances in Consumer Research, 35, 762-763.

Bradley, D., Brown, J., \& Rubach, M. (2010). Iraqi business culture: An expatriate's view. Journal of International Business and Research, 9(2), 21-36.

Chironga, M., Leke, A., Lund, S., \& van Wamelen, A. (2012, May). Cracking the next growth market: Africa. Harvard Business Review, 117-122.

CIA World Factbook. (2020). Africa: Cameroon. Retrieved June 6, 2020, from https://www.cia.gov/library/publications/the-world-factbook/geos/print_cm.html

Dartey-Baah, K. (2013). The cultural approach to the management of the international human resource: An analysis of Hofstede's cultural dimensions. International Journal of Business Administration, $4(2), 39-45$.

Fang, T. (2003). A critique of Hofstede's fifth national culture dimension. International Journal of Cross Cultural Management, 3(3), 347-368

GEERT HOFSTEDE. (2012). Retrieved from www.geert-hofstede.com

Grenness, T. (2012). Hofstede revisited: Is making the ecological fallacy when using Hofstede's instrument on individual behavior really unavoidable? International Journal of Business and Management, 7(7), 75-84.

Hofstede Insights. (n.d.). Country Comparison. Retrieved from www.hofstede-insights.com/countrycomparison

Hofstede, G. (1980a). Culture's consequences: International differences in work-related values. London: Sage Publications.

Hofstede, G. (1980b). Motivation, leadership, and organization: Do American theories apply abroad? Organizational Dynamics, 16(4), 42-63.

Hofstede, G. (1983). The cultural reliability of organizational practices and theories. Journal of International Business Studies, 14, 75-89.

Hofstede, G. (1993). Cultural constraints in management theories. The Executive, 7(1), 81-94.

Hofstede, G. (1994). Management scientists are human. Management Science, 40(1), 4-13.

Hofstede, G. (2001). Culture's Consequences. Thousand Oaks, CA: Sage Publications.

Hofstede, G. (2003). Culture's Consequences: Comparing Values, Behavior, Institutions, and Organizations Across Nations. Thousand Oaks, CA: Sage Publications.

Hofstede, G. (2013). Replicating and extending cross-national value studies: Rewards and pitfalls - An example from Middle East studies. Academy of International Business Insights, 13(2), 5-7.

Hofstede, G., \& Bond, M. (1988). The Confucian connection: From cultural roots to economic growth. Organizational Dynamics, 16(4), 5-21.

Hofstede, G., \& Minkov, M. (2010). Cultures of the Organization: Software of the Mind. New York: McGraw-Hill.

Jackson, T. (2011). From cultural values to cross-cultural interfaces: Hofstede goes to Africa. Journal of Organizational Change Management, 24(4), 532-558.

Kirkman, B., Lowe, K., \& Gibson, C. (2006). A quarter century of "Culture's Consequences": A review of empirical research incorporates Hofstede's cultural values framework. Journal of International Business Studies, 37, 285-320. 
Leke, A., \& Lund, S. (2010, June). What's driving Africa's growth? McKinsey \& Company Report.

MacLachlan, M. (2013). Indulgence vs. Restraint - the $6^{\text {th }}$ Dimension. Retrieved November 3, 2018, from https://www.communicaid.com/cross-cultural-training/blog/indulgence-vs-restraint/

Makambe, U., \& Pellissier, R. (2014). The application of Hofstede's cultural dimensions at Botho University: A model for workplace harmony in a multi-cultural business environment. Information and Knowledge Management, 3(4), 92-99.

McSweeney, B. (2002). Hofstede's model of national cultural differences and their consequences: A triumph. Of faith - a failure of analysis. Human Relations, 55(1), 89-118.

McSweeney, B., Brown, D., \& Lliopoulou, S. (2016). Claiming too much, delivering too little: Testing some of Hofstede's generalizations. Irish Journal of Management, 35(1), 34-57.

Minkov, M. (2013). Cross-Cultural Analysis: The Science and Art of Comparing the World's Modern Societies and their Cultures. Los Angeles: Sage.

Minkov, M., \& Hofstede, G. (2011). The evolution of Hofstede's doctrine. Cross Cultural Management, $18(1), 10-20$.

Moalla, E. (2016). What measure for national culture? Hofstede vs Schwartz vs Globe. Management International, 20, 26-37.

Oppong, N. (2013). Towards African work orientations: Guide from Hofstede's cultural dimensions. European Journal of Business and Management, 5(20), 203-212.

Sagiv, L., \& Schwartz, S. (2007). Cultural values in organizations: Insights for Europe. European Journal of International Management, 1, 176-190.

Scarborough, J. (1998). The Origins of Cultural Differences and their Impact on Management. Westport, CT: Quorum Books.

Sivakumar, K., \& Nakata, C. (2001). The stampede toward Hofstede's framework: Avoiding the sample design pit in cross-cultural research. Journal of International Business Studies, 32(3), 555-574.

Smith, P. (2002). Culture's consequences: Something old and something new. Human Relations, 55(1), $119-135$.

Staff Writer. (2015). Cameroon: 'Africa in miniature” offers a diversity of business opportunities. Retrieved June 6, 2020, from https://www.howwemadeitinafrica.com/cameroon-africa-inminiature-offers-a-diversity-of-business-opportunities/48766/

Swartz, E., \& Davies, R. (1997). Ubuntu - the spirit of African transformation management - A review. Leadership and Organizational Development Journal, 18(6), 290-294.

Trompenaars, F., \& Hampden-Turner, C. (1993). Riding the Waves of Culture: Understanding Cultural Diversity in Business. London: Nicholas Brealey Publishing.

Venaik, S., \& Brewer, P. (2013). Critical issues in the Hofstede and GLOBE national culture models. International Marketing Review, 30(5), 469-482.

Wanasika, I., Howell, J., Littrell, R., \& Dorfman, P. (2011). Managerial leadership and culture in SubSaharan Africa. Journal of World Business, 46(2), 234-241. 